J. Dairy Sci. 95:2779-2787

http://dx.doi.org/10.3168/jds.2011-4655

(C) American Dairy Science Association ${ }^{\circledR}, 2012$.

\title{
Characterization of a Panela cheese with added probiotics and fava bean starch
}

\author{
M. C. Escobar, ${ }^{\star} †$ M. L. Van Tassell,‡ F. Martínez-Bustos,§ M. Singh,\# E. Castaño-Tostado, ${ }^{\star}$ \\ S. L. Amaya-Llano, ${ }^{*}$ and M. J. Miller ${ }^{1}$ \\ *Programa de Posgrado en Alimentos del Centro de la República (PROPAC), Universidad Autónoma de Querétaro, Apdo. Postal 184, \\ Querétaro, QRO 76010, México \\ †CENID Fisiología y Mejoramiento Animal, Instituto Nacional de Investigaciones Forestales Agrícolas y Pecuarias, Ajuchitlán, Colón, \\ QRO 76280, México \\ ‡Department of Food Science and Human Nutrition, University of Illinois, Urbana 61801 \\ §Ciencia de Materiales, CINVESTAV Querétaro, Apdo. Postal 1-798, Querétaro, QRO 76230, México \\ \#US Department of Agriculture, Agricultural Research Service, National Center for Agricultural Utilization Research, Functional Foods Research, \\ Peoria, IL 61604
}

\section{ABSTRACT}

Of 20 Lactobacillus and 8 Bifidobacterium species examined, only Bifidobacterium breve ATCC 15700 was able to ferment starch from fava beans. Bifidobacterium breve ATCC 15700 and Lactobacillus rhamnosus GG ATCC 53103 were selected as probiotics for use in fresh-style Panela cheese. Two types of fresh cheese (with and without $3 \%$ fava bean starch) were manufactured with 3 combinations of probiotics: L. rhamnosus GG only, B. breve only, or both L. rhamnosus GG and B. breve. During $4 \mathrm{wk}$ of storage at $4^{\circ} \mathrm{C}$, the addition of fava bean starch to the cheese was not found to cause significant differences in the viability of either probiotic strain. However, the microstructure and texture of Panela cheese were altered, resulting in a much softer product. A sensory panel showed that the presence of added fava bean starch in Panela cheese was less desirable to consumers, whereas probiotic supplementation had no effect on perceived taste or appearance. Panela cheese could be a suitable food for inclusion of probiotic bacteria.

Key words: Bifidobacterium, Lactobacillus, probiotic cheese, Fresco cheese

\section{INTRODUCTION}

The widely accepted definition of a probiotic is a live microorganism that, when administered in sufficient amount, confers a health benefit to the host. Although no legal regulatory definition of "probiotic" determines the minimum dosage of microorganisms in foods, and dose levels required for efficacy vary by probiotic strain and type of food matrix (Sanders, 2008), daily con-

Received June 24, 2011.

Accepted January 12, 2012.

${ }^{1}$ Corresponding author: mille216@illinois.edu sumption of $100 \mathrm{~g}$ or $100 \mathrm{~mL}$ of food containing populations of probiotic culture of $10^{6}$ to $10^{8} \mathrm{cfu} / \mathrm{g}$ would provide the $10^{8}$ to $10^{10} \mathrm{cfu} / \mathrm{d}$ that has often been demonstrated to be sufficient intake for therapeutic effect (Whorwell et al., 2006; McFarland, 2007). Commonly used probiotic organisms include species of Lactobacillus, Bifidobacterium, Streptococcus, and Saccharomyces.

Food matrices such as fermented milk products have been shown to deliver live probiotic cultures to the intestinal tract (de Vrese et al., 2011), and probiotic bacteria have been incorporated into cheese for years (Dinakar and Mistry, 1994; Hayes et al., 2006; Jayamanne and Adams, 2006). Because of its solid matrix and high fat content, cheese has been shown to be a favorable environment for probiotic bacteria, during both storage and gastrointestinal transit (van den Tempel et al., 2002; Vinderola et al., 2002; Stanton et al., 2005; Bergamini et al., 2005, 2009; Mäkeläinen et al., 2009). Although many cheeses have a $\mathrm{pH}$ ranging between 4.8 and 5.2, Panela cheese is not fermented and has a near neutral $\mathrm{pH}$, which may be advantageous for probiotic survival. The solid matrix and high fat content of Panela cheese are additional factors that are conducive to probiotic addition.

Resistant starch has been widely used as a prebiotic (Topping and Clifton, 2001). Resistant starch is not digested during transit through the small intestine and provides a fermentable substrate for specific microorganisms in the colon. Resistant starch appears to confer considerable health benefits such as reduction in risk of colon cancer, hemorrhoids, diverticulosis, constipation, increased fecal bulking, modulation of blood glucose level, and blood cholesterol level, and it plays a prebiotic role (Sharma et al., 2008). Resistant starch has low water-holding capacity, small particle size, and bland flavor. The use of resistant starch as a prebiotic has only been reported in noncheese dairy products. Crittenden et al. (2001) identified a Bifido- 
Table 1. Lactobacillus and Bifidobacterium species screened for the ability to hydrolyze fava bean starch

\begin{tabular}{|c|c|c|}
\hline Species & Strain $^{1}$ & $\begin{array}{c}\text { Fava bean } \\
\text { starch }^{2}\end{array}$ \\
\hline Lactobacillus gasseri & ATCC 33323 & - \\
\hline Lactobacillus gasseri & $\mathrm{ADH}$ & - \\
\hline Lactobacillus acidophilus & NCFM & - \\
\hline Lactobacillus rhamnosus GG & ATCC 53103 & - \\
\hline Lactobacillus johnsonii & ATCC 53103 & - \\
\hline Lactobacillus casei & ATCC 393 & - \\
\hline Lactobacillus delbrueckii ssp. bulgaricus & ATCC 11842 & - \\
\hline Lactobacillus delbrueckii ssp. lactis & ATCC 4797 & - \\
\hline Lactobacillus rhamnosus & ATCC 7469 & - \\
\hline Lactobacillus fermentum & ATCC 9338 & - \\
\hline Lactobacillus acidophilus & ATCC 4356 & - \\
\hline Lactobacillus casei ssp. casei & ATCC 334 & - \\
\hline Lactobacillus helveticus & ATCC 15009 & - \\
\hline Lactobacillus pentosus & ATCC 8041 & - \\
\hline Lactobacillus plantarum & ATCC 14917 & - \\
\hline Lactobacillus fermentum & ATCC 14931 & - \\
\hline Lactobacillus curvatus ssp. curvatus & ATCC 25601 & - \\
\hline Lactobacillus delbrueckii ssp. delbrueckii & ATCC 9649 & - \\
\hline Lactobacillus delbrueckii ssp. lactis & ATCC 12315 & - \\
\hline Lactobacillus delbrueckii ssp. bulgaricus & ATCC 7993 & - \\
\hline Bifidobacterium adolescentis & ATCC15703 & - \\
\hline Bifidobacterium infantis, S12 & ATCC 15897 & - \\
\hline Bifidobacterium animalis ssp. lactis & DSM10140 & - \\
\hline Bifidobacterium animalis ssp. animalis & ATCC 25527 & - \\
\hline Bifidobacterium bifidum & ATCC 29521 & - \\
\hline Bifidobacterium breve & ATCC 15700 & + \\
\hline Bifidobacterium longum & ATCC 15707 & - \\
\hline Bifidobacterium bifidum & ATCC 11617 & - \\
\hline
\end{tabular}

${ }^{1}$ ATCC = American Type Culture Collection (Manassas, VA); DSM = Deutsche Sammlung von Mikroorganismen und Zellkulturen GmbH (Braunschweig, Germany). Lactobacillus gasseri ADH is a noncommercial laboratory strain (Kleeman and Kleinhammer, 1982); and Lactobacillus acidophilus NCFM is a commercial strain (Gilliland et al., 1975).

${ }^{2}$ The ability or inability to utilize fava bean starch is represented by "+" or "-" respectively.

bacterium species that survived storage at $4^{\circ} \mathrm{C}$ for $5 \mathrm{wk}$ in yogurt containing resistant starch and inulin without substantial loss of viability. Homayouni et al. (2008) reported no significant effect on taste when ice cream was supplemented with $1 \%$ resistant starch as a prebiotic and encapsulated Lactobacillus and Bifidobacterium strains as probiotics. However, no studies have examined the effects of resistant starch supplementation on the physical characteristics of fresh cheese. The aim of this investigation was to manufacture and evaluate a Mexican fresh cheese (Panela) made with the inclusion of probiotic bacteria and fava bean starch, which naturally has a high concentration of resistant starch.

\section{MATERIALS AND METHODS}

\section{Microorganisms and Culture Conditions}

Twenty Lactobacillus and 8 Bifidobacterium species, mostly available from the American Type Culture Collection (ATCC, Manassas, VA), were screened. These organisms are listed in Table 1. The cultures were revived from frozen glycerol stocks $\left(-20^{\circ} \mathrm{C}\right)$ by subculturing twice in de Man, Rogosa, Sharpe broth (MRS;
Becton Dickinson and Co., Franklin Lakes, NJ) for lactobacilli and Reinforced Clostridial Medium broth (Difco, Becton Dickinson and Co.) for bifidobacteria, using a $1 \%$ (vol/vol) inoculum. Cultures were incubated at $37^{\circ} \mathrm{C}$ in an anaerobic chamber consisting of $5 \% \mathrm{CO}_{2}$, $5 \% \mathrm{H}_{2}$, and $90 \% \mathrm{~N}_{2}$ (Coy Laboratory Products Inc., Grass Lake, MI).

\section{Extraction of Fava Bean Starch}

One kilogram of fava beans (Vicia faba L.) was milled in a Pyrex mill, soaked in $3 \mathrm{~L}$ of $0.05 \mathrm{~N} \mathrm{NaOH}$ overnight at $5^{\circ} \mathrm{C}$, and then subjected to wet milling. The suspension was filtered through 30-, 100-, and 200-mesh sieves (US standard), and the residues retained on each screen were washed with water to recover the starch. The starch extract was allowed to stand overnight at $5^{\circ} \mathrm{C}$ to drain excess water and was then dried at $40^{\circ} \mathrm{C}$ and stored in plastic bags at room temperature $\left(24^{\circ} \mathrm{C}\right)$. The amount of resistant starch in the starch extract was measured using the enzymatic method of Goñi et al. (1996). Analysis of moisture, protein content, lipid content, and ash of the starch extract were performed by using official procedures of AOAC (2000). 


\section{Hydrolysis of Fava Bean Starch}

The ability of lactobacilli and bifidobacteria to hydrolyze fava bean starch was evaluated using agar plates containing fava bean starch or glucose as the sole carbon source. The growth medium was MRS and either $30 \mathrm{~g} / \mathrm{L}$ fava bean starch or glucose was the sole carbohydrate. The same medium was used for bifidobacteria growth, supplemented with $0.5 \mathrm{~g} / \mathrm{L}$ L-cysteine$\mathrm{HCl}$ (Fisher Scientific, Pittsburgh, PA). Cultures were anaerobically incubated for $48 \mathrm{~h}$ at $37^{\circ} \mathrm{C}$. Following incubation, each plate was flooded with a solution of $10 \mathrm{~g} / \mathrm{L}$ iodine and $20 \mathrm{~g} / \mathrm{L}$ potassium iodide. A clear zone was observed around colonies able to hydrolyze the substrate.

\section{Panela Cheese Manufacturing}

Fava bean starch $(3 \% \mathrm{wt} / \mathrm{vol})$ was added to fresh whole milk, pasteurized at $75^{\circ} \mathrm{C}$ for $15 \mathrm{~s}$, and then cooled to $37^{\circ} \mathrm{C}$. Lactobacilli, bifidobacteria, or both were then added to the milk to a final concentration of $10^{8} \mathrm{cfu} / \mathrm{mL}$. After $45 \mathrm{~min}$, calcium chloride $(20 \mathrm{~g} / 100 \mathrm{~L}$ of milk) and rennet $(15 \mathrm{~mL} / 100 \mathrm{~L}$ of milk) were added. When the curd firmed, it was cut into small cubes. The curds were stirred slowly at $37^{\circ} \mathrm{C}$ for $30 \mathrm{~min}$, and then cooked at $39^{\circ} \mathrm{C}$ for $10 \mathrm{~min}$ to draw whey from the curd grains. After the whey was removed, the curds were salted (11 g of salt/L of milk) and transferred to cheese molds to be stored at $4^{\circ} \mathrm{C}$ for $4 \mathrm{wk}$. The cheese was sampled to measure $\mathrm{pH}$, bacterial viability, and lipid, protein, and moisture contents after 1, 7, 15, 21, and 30 d, within its approximate 15 - to 30 -d shelf-life.

\section{Cheese Compositional Analysis}

The Panela cheese samples were analyzed in triplicate. A pH meter (Mettler Toledo, Columbus, OH) determined sample $\mathrm{pH}$; moisture content was determined by heating $2.0-\mathrm{g}$ samples at $105^{\circ} \mathrm{C}$ to constant weight (AOAC, 2000; method 926.08); fat content was measured via the Gerber method (AOAC, 2000; method 18); and total protein was measured via the Kjeldahl method (AOAC, 2000; method 920.123).

\section{Viability of Probiotic Bacteria in Cheese}

Viable counts of lactobacilli and bifidobacteria were estimated after $1,7,15,21$, and $30 \mathrm{~d}$ of storage at $4^{\circ} \mathrm{C}$. Ten-gram samples of cheese were homogenized in 90 $\mathrm{mL}$ of sterile sodium citrate solution $(2 \% \mathrm{wt} / \mathrm{vol})$ for 3 min in a Stomacher 400 (Seward Laboratory Systems Inc., Port Saint Lucie, FL). Subsequent dilutions were made in sterilized water containing $1 \mathrm{~g} / \mathrm{L}$ peptone and
$9 \mathrm{~g} / \mathrm{L}$ sodium chloride. The enumeration of lactobacilli was performed using Lactobacillus Selection agar medium (BD BBL, Becton Dickinson and Co.) acidified with $1.32 \mathrm{~mL}$ of glacial acetic acid/L of medium. Enumeration of bifidobacteria was performed with MRS- $0.05 \%$ cysteine-HCl. When both probiotics were included, lactobacilli were enumerated with LBS, total probiotic counts were determined using MRS- $0.05 \%$ cysteine- $\mathrm{HCl}$, and the bifidobacteria count was determined by subtracting the lactobacilli count from the total. Enumeration of lactobacilli and bifidobacteria was also performed with noninoculated control cheese. The cultures were incubated at $37^{\circ} \mathrm{C}$ for $48 \mathrm{~h}$ under anaerobic conditions. Viable cell counts were performed in triplicate.

\section{Microstructure Determination}

Scanning electron microscopy was used to examine the changes in cheese microstructure. Cheese samples were fixed in $2 \%$ paraformaldehyde and $2.5 \%$ glutaraldehyde in $0.1 M$ Na-cacodylate buffer ( $\mathrm{pH} 7.4$ ) for $24 \mathrm{~h}$, then transferred to $0.1 M$ Na-cacodylate buffer ( $\mathrm{pH} 7.4$ ) for $30 \mathrm{~min}$ on a shaker table. Samples were then dehydrated in increasing concentrations of aqueous ethanol solutions $(37,67,95$, and $100 \%)$ for 30 min each while on the shaker table. Samples were dried in a CPA II Technics Critical Point Dryer (Tousimis, Rockville, MD). Cheese samples were mounted and then coated with a thin layer of gold-palladium in a Denton Desk II TSC turbo-pumped sputter coater (Denton Vacuum, Moorestown, NJ). A Philips high-vacuum field-emission environmental scanning electron microscope (Philips XL30 ESEM-FEG, FEI Co., Hillsboro, OR), at $5 \mathrm{kV}$ spot size 3 , was used to view each sample at magnifications of $1,500,2,500$, and $10,000 \times$.

\section{Penetration Test of Fava Bean Starch-Containing Cheese}

Firmness of the cheese with added fava bean starch was compared with the control through penetration testing in a texture analyzer (TA-XT2, Texture Technologies Corp., Scarsdale, NY). The samples of Panela cheese (200 g) were analyzed immediately after removal from storage at $5^{\circ} \mathrm{C}$. The tests were carried out at a speed of $1 \mathrm{~mm} / \mathrm{s}$ and a penetration distance of $10 \mathrm{~mm}$ using a 5-mm diameter cylinder $(\mathrm{P} / 5)$ using 5 - $\mathrm{kg}$ load cell.

\section{Sensory Analysis}

The sensory evaluation was performed in 2 phases. The first phase was made to define descriptive "con- 
structs" generated by the panelists. In the second phase, the chosen constructs were applied to measure panelist responses (Raats, 1992). The first phase evaluated 8 samples of Panela cheese: samples with and without the addition of probiotic bacteria and samples with and without added bean starch. The panel consisted of 24 participants between 20 and 60 yr of age, 9 male and 15 female, interviewed individually. The evaluation was conducted via triangle test. A group of 3 cheeses was placed before each of the panelists, who then were asked to identify the 2 samples that were the same and identify a construct that described the similitude. Panelists were not asked to elaborate on differences between samples. This procedure was repeated with each of 4 triads of cheese. Panel responses (constructs) were recorded and those with a frequency $<25 \%$ were not included in the analysis of consumer acceptability of the samples.

The second sensory evaluation phase used the selected descriptors with greater consensus generated in the first phase of the sensory evaluation; then, an affective test was carried out among consumers to measure preference or acceptance of cheese based on the previously generated constructs. The second panel comprised 100 consumer participants. Eight cheese samples were rated on an acceptance scale from 1 (dislike very much) to 7 (like very much) points.

\section{Statistical Analyses}

To study the survival of probiotics in cheese with and without fava bean starch, cheese was made in a $4 \times 2$ factorial design, randomized with 3 replicates. The first factor (2 levels) was cheese type: whether or not the cheese contained fava bean starch. The second factor $(4$ levels) was probiotic type: the presence of Lactobacillus rhamnosus GG ATCC 53103, Bifidobacterium breve ATCC 15700 both, or neither. The results were analyzed using JMP 5.0.1.2 (SAS Institute Inc., Cary, NC) to determine the statistical significance of differences. Sensory analysis data were analyzed using the nonparametric Friedman test, and multiple comparisons were determined applying Bonferroni test at $\alpha=0.05$, using XLSTAT 2009 (Addinsoft Inc., New York, NY).

\section{RESULTS AND DISCUSSIONS}

\section{Starch}

The resistant starch content of the fava beans was measured to be $5.9 \%$ (wt/wt). The starch contained $10.59 \% \pm 0.011$ moisture, $0.35 \% \pm 0.270(\mathrm{~N} \times 6.25)$ protein, $0.15 \% \pm 0.029$ fat, and $0.06 \% \pm 0.056$ ash content. The results indicate that fava bean starch has similar composition to that of other legumes (Ratnayake et al., 2001; Guillon and Champ, 2002).

\section{Hydrolysis of Fava Bean Starch}

Twenty lactobacilli and 8 bifidobacteria were screened for their ability to ferment fava bean starch using a modified MRS medium containing fava bean starch as the sole carbohydrate. Most of these strains (26 of 28) are readily available in culture collections and cover a wide diversity of lactobacilli and bifidobacteria. In addition, we included several species that are often used as starter cultures because these have been implicated to have probiotic potential (Aihara et al., 2005; Elmadfa et al., 2010; Makino et al., 2010). Four lactobacilli (L. rhamnosus ATCC 7469, L. rhamnosus GG ATCC 53103, Lactobacillus casei ATCC 393, and Lactobacillus delbrueckii ssp. bulgaricus ATCC 11842) and one bifidobacterium (B. breve ATCC 15700) were able to form colonies on MRS-fava bean starch. The MRS-fava bean starch plates containing colonies from the 5 positive strains were then tested for the presence of starch hydrolysis using an iodine test. Only B. breve ATCC 15700 hydrolyzed enough starch to generate a clear zone around the colony, demonstrating its ability to hydrolyze fava bean starch. Previous studies have shown that the amylose content in starch determines its enzymatic resistance to hydrolysis (Brown et al., 1995; Tharanathan and Mahadevamma, 2003; Yanagisawa et al., 2006) and increases the capability of colonic bacteria to ferment resistant starch. Our findings show that B. breve ATCC 15700 could ferment fava bean starch as its sole carbon source. These results were in accordance with Crittenden et al. (2001), who observed bifidobacteria that were able to hydrolyze resistant starch.

\section{Viability of Probiotic Bacteria in Cheese}

The viability of $L$. rhamnosus $\mathrm{GG}$ and $B$. breve ATCC 15700 in Panela cheese with and without fava starch, during storage at $4^{\circ} \mathrm{C}$, is depicted in Table 2 . The results of the ANOVA indicated that the addition of fava starch to the Panela cheese did not have a significant effect $(P=0.46)$ on the viability of the probiotic bacteria during $30 \mathrm{~d}$ of storage at $4^{\circ} \mathrm{C}$. No significant interaction between the type of cheese and the type of probiotic was detected $(P=0.91)$; however, a significant difference $(P<0.0001)$ was observed between changes in bacterial viability during storage. Lactobacillus rhamnosus GG showed an increase in both cheeses of approximately $0.25 \mathrm{log} \mathrm{cfu} / \mathrm{g}$ during $30 \mathrm{~d}$ of storage. In cheese with fava bean starch, $B$. breve decreased approximately $0.5 \mathrm{log} \mathrm{cfu} / \mathrm{g}$ over 30 $\mathrm{d}$, whereas, in cheese without fava bean starch, the 
Table 2. Viability and $\mathrm{pH}$ of probiotic bacteria during $30 \mathrm{~d}$ of storage at $4^{\circ} \mathrm{C}^{1,2}$

\begin{tabular}{|c|c|c|c|c|c|}
\hline Probiotic & $\begin{array}{c}\text { Time } \\
(\mathrm{d})\end{array}$ & \multicolumn{2}{|c|}{$\mathrm{FBS}+$} & \multicolumn{2}{|c|}{ FBS- } \\
\hline \multirow[t]{4}{*}{ Noninoculated control } & 1 & $6.40^{\mathrm{a}} \pm 0.24$ & $\mathrm{ND}^{3}$ & $6.58^{\mathrm{a}} \pm 0.01$ & ND \\
\hline & 15 & $6.45^{\mathrm{a}} \pm 0.05$ & ND & $6.55^{\mathrm{a}} \pm 0.04$ & ND \\
\hline & 21 & $6.48^{\mathrm{a}} \pm 0.07$ & ND & $6.38^{\mathrm{a}} \pm 0.17$ & ND \\
\hline & 30 & $6.53^{\mathrm{a}} \pm 0.12$ & ND & $6.52^{\mathrm{a}} \pm 0.02$ & ND \\
\hline \multirow{3}{*}{ Lactobacillus rhamnosus GG ATCC 53103} & 15 & $6.15^{\mathrm{a}} \pm 0.07$ & $8.79^{\mathrm{a}} \pm 0.13$ & $6.27^{\mathrm{a}} \pm 0.09$ & $8.77^{\mathrm{a}} \pm 0.12$ \\
\hline & 21 & $6.15^{\mathrm{a}} \pm 0.03$ & $8.78^{\mathrm{a}} \pm 0.09$ & $6.24^{\mathrm{a}} \pm 0.04$ & $8.79^{\mathrm{a}} \pm 0.14$ \\
\hline & 30 & $6.10^{\mathrm{a}} \pm 0.20$ & $8.73^{\mathrm{a}} \pm 0.07$ & $6.29^{\mathrm{a}} \pm 0.04$ & $8.84^{\mathrm{a}} \pm 0.19$ \\
\hline \multirow[t]{4}{*}{ Bifidobacterium breve ATCC 15700} & 1 & $6.20^{\mathrm{a}} \pm 0.08$ & $8.29^{\mathrm{b}} \pm 0.27$ & $6.20^{\mathrm{a}} \pm 0.08$ & $8.59^{\mathrm{b}} \pm 0.17$ \\
\hline & 7 & $6.17^{\mathrm{a}} \pm 0.07$ & $8.02^{\mathrm{b}} \pm 0.50$ & $6.23^{\mathrm{a}} \pm 0.11$ & $8.49^{\mathrm{b}} \pm 0.07$ \\
\hline & 15 & $6.16^{\mathrm{a}} \pm 0.09$ & $8.21^{\mathrm{b}} \pm 0.37$ & $6.14^{\mathrm{a}} \pm 0.14$ & $8.43^{\mathrm{b}} \pm 0.06$ \\
\hline & 21 & $6.14^{\mathrm{a}} \pm 0.08$ & $7.97^{\mathrm{b}} \pm 0.45$ & $6.17^{\mathrm{a}} \pm 0.11$ & $8.05^{\mathrm{b}} \pm 0.31$ \\
\hline L. rhamnosus GG and B. breve ${ }^{4}$ & 30 & $5.60^{\mathrm{a}} \pm 0.12$ & $9.01^{\mathrm{a}} \pm 0.10$ & $5.71^{\mathrm{a}} \pm 0.24$ & $8.93^{\mathrm{a}} \pm 0.10$ \\
\hline
\end{tabular}

\footnotetext{
$\overline{\mathrm{a}, \mathrm{b}}$ For each column considered, values with the same superscript are not statistically different $(P>0.05)$.

${ }^{1}$ Values are the means of 3 replicates \pm SD.

${ }^{2} \mathrm{FBS}+=$ with added fava bean starch; FBS $-=$ no added fava bean starch.

${ }^{3}$ Not detected.

${ }^{4}$ For cheese with both probiotics added, the total probiotic count is shown.
}

bacteria decreased $1 \log \mathrm{cfu} / \mathrm{g}$. Nevertheless, at the end of the storage period, the viability of $B$. breve in both cheeses remained within the levels $\left(10^{6}\right.$ to $\left.10^{8} \mathrm{cfu} / \mathrm{g}\right)$ that could confer probiotic effect.

In Cheddar cheese, one of the most studied cheese models, probiotics have also been shown to survive well and have little effect on pH (Dinakar and Mistry, 1994; McBrearty et al., 2001), although Cheddar has a much lower moisture content than Panela. Similar studies have been performed in fresh cheeses such as cottage cheese. For example, Blanchette et al. (1996) reported that cell concentrations of Bifidobacterium infantis in cottage cheese, initially present at approximately $10^{7}$ $\mathrm{cfu} / \mathrm{g}$ at $\mathrm{pH}$ between 4.5 and 6 , declined rapidly after $15 \mathrm{~d}$ of storage at $4^{\circ} \mathrm{C}$. According to the authors, this behavior was attributed to the $\mathrm{pH}$, which did not favor the survival of bifidobacteria during storage. Similarly, Roy et al. (1997) reported the viability of $B$. breve and Bifidobacterium longum in cottage cheese, which started at approximately $10^{8} \mathrm{cfu} / \mathrm{g}$, but quickly declined to $10^{5}$ and $10^{6} \mathrm{cfu} / \mathrm{g}$, respectively, after $15 \mathrm{~d}$ of storage at $4^{\circ} \mathrm{C}$, with corresponding $\mathrm{pH}$ values between 6 and 6.5. Montoya et al. (2009) evaluated the viability of 3 types of bifidobacteria (B. breve R0070, B. infantis R0033, and B. longum R0175) and Pediococcus acidilactici R1001 in the curds of Swiss cheese. These authors reported that the viability of these bacteria was maintained around
$10^{8} \mathrm{cfu} / \mathrm{g}$ at a $\mathrm{pH}$ between 6.2 and 6.5 after $10 \mathrm{~d}$ of storage at $37^{\circ} \mathrm{C}$.

Panela cheese samples showed similar $\mathrm{pH}$ profiles. The cheeses containing $B$. breve or $L$. rhamnosus GG had $\mathrm{pH}$ values of 6.20 and 6.24 , respectively, at $\mathrm{d} 1$, and $\mathrm{pH}$ values of 6.06 and 6.09 after $30 \mathrm{~d}$ of storage. The differences in $\mathrm{pH}$ between the cheeses were not significant $(P=0.58)$. The $\mathrm{pH}$ of the cheese without fava bean starch was 6.10 and 5.71 after 1 and $30 \mathrm{~d}$ of storage, respectively, whereas the cheese with fava bean starch had a pH of 5.87 and 5.60 at 1 and $30 \mathrm{~d}$, respectively (Table 2 ).

The cheese $\mathrm{pH}$ favored the survival of $B$. breve, because the optimum $\mathrm{pH}$ for Bifidobacterium spp. is between 6.5 and 7.0, with growth inhibited at values below pH 5.0 (Boylston et al., 2004). It has been reported that $B$. breve limits metabolic activity and acid production under anaerobic conditions (Shimamura et al., 1992), which are created in the compact structure of the Panela cheese. On the other hand, the processing temperature of the Panela cheese $\left(37\right.$ to $\left.39^{\circ} \mathrm{C}\right)$ facilitates the growth of $B$. breve, because the optimum growth temperature of many bifidobacteria is between 36 and $38^{\circ} \mathrm{C}$. The viability counts from the combined culture cheeses increased in the samples with and without fava bean starch by 0.29 and $0.1 \mathrm{log} \mathrm{cfu} / \mathrm{g}$, respectively, after $30 \mathrm{~d}$ of storage, indicating the maintenance 
Table 3. Composition of Panela fresh cheese made with and without probiotic strains (Lactobacillus rhamnosus GG and Bifidobacterium breve $)^{1,2}$

\begin{tabular}{llccc}
\hline $\begin{array}{l}\text { Cheese } \\
\text { type }\end{array}$ & $\begin{array}{l}\text { Probiotic } \\
\text { strain }\end{array}$ & $\begin{array}{c}\text { Moisture } \\
(\%)\end{array}$ & $\begin{array}{c}\text { Fat } \\
(\%)\end{array}$ & $\begin{array}{c}\text { Protein } \\
(\%)\end{array}$ \\
\hline FBS+ & B. breve & $72.17^{\mathrm{a}} \pm 2.57$ & $12.83^{\mathrm{a}} \pm 2.02$ & $27.89^{\mathrm{a}} \pm 1.88$ \\
& L. rhamnosus GG & $71.83^{\mathrm{a}} \pm 3.21$ & $15.83^{\mathrm{a}} \pm 3.33$ & $29.44^{\mathrm{a}} \pm 0.90$ \\
& Both strains & $68.67^{\mathrm{a}} \pm 1.01$ & $14.67^{\mathrm{a}} \pm 3.21$ & $26.85^{\mathrm{a}} \pm 1.02$ \\
& Control cheese & $73.33^{\mathrm{a}} \pm 3.25$ & $13.00^{\mathrm{a}} \pm 2.88$ & $32.02^{\mathrm{a}} \pm 2.29$ \\
FBS- & B. breve & $59.17^{\mathrm{b}} \pm 1.15$ & $13.33^{\mathrm{a}} \pm 1.76$ & $27.19^{\mathrm{a}} \pm 2.12$ \\
& L. rhamnosus GG & $59.17^{\mathrm{b}} \pm 1.61$ & $17.33^{\mathrm{a}} \pm 2.02$ & $28.35^{\mathrm{a}} \pm 2.52$ \\
& Both strains & $61.83^{\mathrm{b}} \pm 1.89$ & $12.67^{\mathrm{a}} \pm 2.25$ & $29.74^{\mathrm{a}} \pm 3.39$ \\
& Control cheese & $58.83^{\mathrm{b}} \pm 1.58$ & $14.00^{\mathrm{a}} \pm 3.12$ & $28.31^{\mathrm{a}} \pm 0.08$ \\
\hline
\end{tabular}

${ }^{a, b}$ For each column considered, values with the same superscript are not statistically different $(P>0.05)$.

${ }^{1}$ Values are the means of 3 replicates $\pm \mathrm{SD}$.

${ }^{2} \mathrm{FBS}+=$ with added fava bean starch; FBS $-=$ no added fava bean starch.

of satisfactory viability of the probiotic blend in both cheeses. Vinderola et al. (2000) evaluated the development of different combinations of bifidobacteria and lactobacilli in a fresh Argentine cheese. These authors reported that 9 combinations of Bifidobacterium and Lactobacillus acidophilus decreased in viability by less than $1 \log$ after $60 \mathrm{~d}$ of storage and that 2 combinations of Bifidobacterium and L. casei decreased at least 1 log for bifidobacteria, but maintained bacterial levels around $10^{6} \mathrm{cfu} / \mathrm{g}$.

\section{Compositional Analyses of the Panela Cheese}

The composition of the Panela cheese with and without addition of fava bean starch and probiotic bacteria is shown in Table 3 . None of these cheeses showed significant differences in fat $(P=0.69)$ or protein contents $(P=0.14)$. However, a significant difference in moisture content was observed $(P<0.0001)$. Cheese with added starch showed higher moisture content (from 68 to $73 \%$ ) than cheese without fava bean starch (from 58 to $61 \%$ ); this is likely because when the blend of milk ( $88 \%$ water content) and fava bean starch is pasteurized at $75^{\circ} \mathrm{C}$, the starch is gelatinized and water is absorbed into the starch granules, preventing its usual release during whey separation.

\section{Microstructure Determination}

Scanning electron microscopy was used to observe the effect of fava bean starch and probiotic bacteria in the microstructure of the cheeses. In Figure 1A and 1C, the Panela cheese without fava bean starch showed a continuous 3-dimensional network with rhomboid and circular voids of different sizes uniformly distributed in a compact structure. In the cheese containing fava bean starch (Figure 1B and 1D), a very open amorphous matrix with some voids was observed and starch granules could be seen embedded in the protein matrix. The differences in the structure of these cheeses can be attributed to a thermodynamic incompatibility between milk proteins and starch (Tolstoguzov, 2003).

\section{Penetration Test of Cheese with Added Fava Bean Starch}

Data analysis of the force required for the penetration of cheeses with and without fava bean starch or probiotic bacteria is shown in Table 4 . The addition of bacteria did not have a significant effect $(P=0.06)$ on the penetration resistance of either cheese. However, the presence or absence of fava starch resulted in significant differences in firmness of the cheeses $(P=0.004)$. The cheeses with fava starch showed lower penetration strength values than the cheeses with no fava bean starch; because the cheese containing fava starch had significantly higher moisture content, it also provided less resistance during penetration testing. The physical properties of cheese are affected by the fat, protein, and moisture contents, as well as by the processing technology and intensity of proteolysis (Jaros et al., 2001). Increased water content loosens the protein structure in cheese, whereas decreasing the water content results in a firmer cheese (Castañeda, 2002). As observed in the

Table 4. Penetration force values for Panela cheese made with and without probiotic strains (Lactobacillus rhamnosus GG and Bifidobacterium breve $)^{1,2}$

\begin{tabular}{llr}
\hline $\begin{array}{l}\text { Cheese } \\
\text { type }\end{array}$ & $\begin{array}{l}\text { Probiotic } \\
\text { strain }\end{array}$ & \multicolumn{1}{c}{$\begin{array}{c}\text { Force } \\
(\mathrm{g})\end{array}$} \\
\hline FBS+ & Control cheese & $102^{\mathrm{ab}} \pm 0.01$ \\
& With probiotics & $70^{\mathrm{b}} \pm 0.05$ \\
FBS- & Control cheese & $170^{\mathrm{a}} \pm 0.02$ \\
& With probiotics & $127^{\mathrm{ab}} \pm 0.01$ \\
\hline
\end{tabular}

$\overline{\mathrm{a}, \mathrm{b}}$ Values with the same superscript are not statistically different $(P$ $>0.05)$.

${ }^{1}$ Values are the means of 3 replicates $\pm \mathrm{SD}$.

${ }^{2} \mathrm{FBS}+=$ with added fava bean starch; FBS $-=$ no added fava bean starch. 

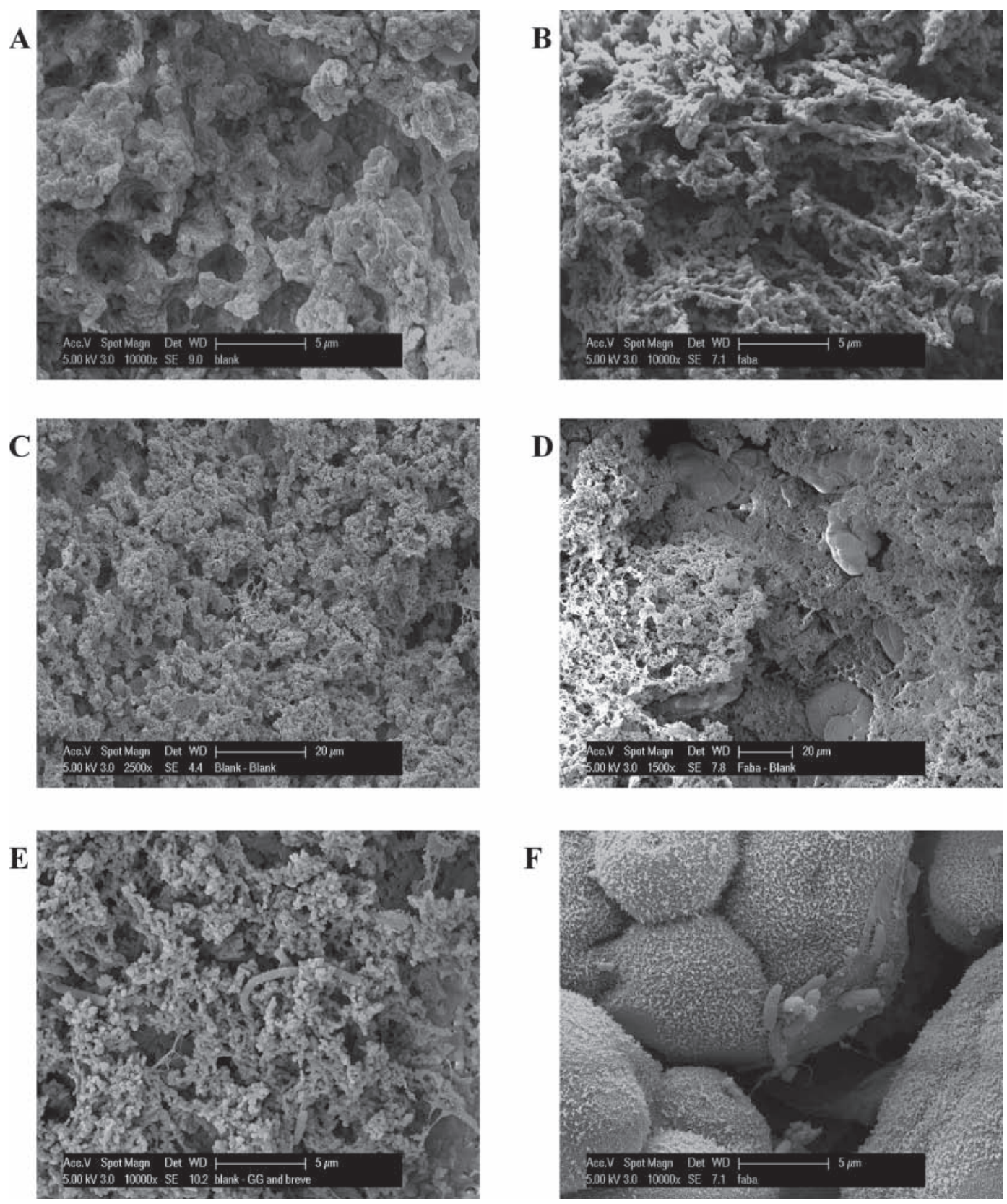

Figure 1. Microstructure of Panela cheese samples without added fava bean starch (panels A and C); without added fava bean starch but with added probiotic (Lactobacillus rhamnosus GG ATCC 53103 and Bifidobacterium breve ATCC 15700; panel E); with added fava bean starch (panels B and D); with added fava bean starch and probiotics (L. rhamnosus GG ATCC 53103 and B. breve ATCC 15700; panel F).

micrographs in Figure 1, starch granules were not fully integrated into the protein matrix, indicating that the fava starch may have loosened the protein structure of the fresh Panela cheese directly as well.

\section{Sensory Analysis}

A selected descriptors test was conducted with 24 consumers between 20 and $60 \mathrm{yr}$ of age who consume fresh cheese at least once a week. Panelist-generated descriptors that were similar in meaning were integrated into a single construct. Descriptors reported by over $25 \%$ of the panel were considered in subsequent analysis.

The attributes to be assessed were appearance and flavor. Four descriptors were measured for appearance: compactness, hardness, moisture, and softness. Three descriptors were evaluated for cheese flavor: milk fla- 
Table 5. Results of a multiple comparison test for sensory evaluation performed for cheeses with and without fava bean starch and probiotic strains (Lactobacillus rhamnosus GG and Bifidobacterium breve)

\begin{tabular}{|c|c|c|c|c|c|c|c|c|}
\hline \multirow[b]{2}{*}{$\begin{array}{l}\text { Cheese } \\
\text { type }^{1}\end{array}$} & \multirow[b]{2}{*}{$\begin{array}{l}\text { Probiotic } \\
\text { strain }\end{array}$} & \multicolumn{4}{|c|}{ Appearance } & \multicolumn{3}{|c|}{ Flavor } \\
\hline & & Compact & Hard & Moist & Soft & $\begin{array}{l}\text { Creamy } \\
\text { flavored }\end{array}$ & $\begin{array}{c}\text { Milk } \\
\text { flavored }\end{array}$ & Sour \\
\hline \multirow[t]{4}{*}{$\overline{\mathrm{FBS}+}$} & L. rhamnosus GG & $293.5^{\mathrm{b}}$ & $305^{\mathrm{b}}$ & $297.5^{\mathrm{a}}$ & $326.5^{\mathrm{b}}$ & $281.5^{\mathrm{ab}}$ & $299^{\mathrm{b}}$ & $343.5^{\mathrm{cd}}$ \\
\hline & B. breve & $248.5^{\mathrm{ab}}$ & $259^{\mathrm{ab}}$ & $306.5^{\mathrm{a}}$ & $263.5^{\mathrm{a}}$ & $283.5^{\mathrm{ab}}$ & $229.5^{\mathrm{a}}$ & $222.5^{\mathrm{a}}$ \\
\hline & Both strains & $204^{\mathrm{a}}$ & $214^{\mathrm{a}}$ & $308.5^{\mathrm{a}}$ & $256^{\mathrm{a}}$ & $280^{\mathrm{ab}}$ & $313.5^{\mathrm{b}}$ & $313^{\mathrm{bc}}$ \\
\hline & Control cheese & $290^{\mathrm{b}}$ & $282^{\mathrm{b}}$ & $292^{\mathrm{a}}$ & $257^{\mathrm{a}}$ & $229^{\mathrm{a}}$ & $208^{\mathrm{a}}$ & $257.5^{\mathrm{ab}}$ \\
\hline \multirow[t]{4}{*}{ FBS- } & L. rhamnosus GG & $427^{\mathrm{c}}$ & $440.5^{\mathrm{c}}$ & $460.5^{\mathrm{c}}$ & $426^{\mathrm{d}}$ & $336.5^{\mathrm{bc}}$ & $482^{\mathrm{d}}$ & $376^{\mathrm{d}}$ \\
\hline & B. breve & $417^{\mathrm{c}}$ & $431.5^{\mathrm{c}}$ & $420^{\mathrm{bc}}$ & $356.5^{\mathrm{bc}}$ & $391^{\mathrm{c}}$ & $489^{\mathrm{d}}$ & $377.5^{\mathrm{d}}$ \\
\hline & Both strains & $394^{\mathrm{c}}$ & $427.5^{\mathrm{c}}$ & $388.5^{\mathrm{b}}$ & $389.5^{\mathrm{cd}}$ & $388^{\mathrm{c}}$ & $483^{\mathrm{d}}$ & $375^{\mathrm{d}}$ \\
\hline & Control cheese & $390^{\mathrm{c}}$ & $412.5^{\mathrm{c}}$ & $406.5^{\mathrm{bc}}$ & $353^{\mathrm{bc}}$ & $330.5^{\mathrm{b}}$ & $412^{\mathrm{c}}$ & $362.5^{\mathrm{cd}}$ \\
\hline
\end{tabular}

${ }^{\mathrm{a}-\mathrm{d}}$ For each column considered, values with the same superscript are not statistically different $(P>0.05)$.

${ }^{1} \mathrm{FBS}+=$ with added fava bean starch; FBS- = no added fava bean starch.

vor, creamy flavor, and sourness. The cheeses without starch showed greater consumer acceptance across all constructs compared with cheeses containing added starch (Table 5).

The starchless cheese containing L. rhamnosus GG showed greater consumer acceptance in the compactness, hardness, moisture, and softness descriptors, whereas the starchless cheese containing $B$. breve had the greatest acceptance in creamy and milky flavor constructs. The starchless cheese containing the mixture of both strains showed greater acceptance for the sourness descriptor. In addition, consumers showed equal or greater acceptance of cheeses with probiotic bacteria compared with control cheeses. According to consumers, probiotic bacteria do not affect flavor and appearance of the Panela cheese, in agreement with results reported by other authors. De Souza et al. (2008) reported that the addition of probiotic cultures (L. acidophilus La-5) to Minas fresh cheese had good acceptance after 7 and $14 \mathrm{~d}$ of storage. Gardiner et al. (1998) and Stanton et al. (1998) reported that Cheddar cheese containing Lactobacillus paracasei and Lactobacillus salivarius did not show sensorial changes in flavor and texture compared with the control.

\section{Future Directions}

One potential health benefit of probiotics is the antilisterial activity demonstrated for select strains (Corr et al., 2007; Mills et al., 2011). Future studies will evaluate the use of antilisterial probiotics in fresh cheeses in which Listeria monocytogenes is a significant concern. Further research in the incorporation of probiotics into foods may include bacteriocin production as a screening tool instead of examining interactions with prebiotics.

\section{CONCLUSIONS}

Bifidobacterium breve ATCC 15700 hydrolyzed fava bean starch, but inclusion of fava bean starch in Panela cheese formulation did not increase probiotic survival during storage. Nevertheless, survival of probiotic bacteria in fresh Panela cheese was observed throughout its 30-d shelf-life, with or without the addition of fava bean starch. The starch conferred decreased firmness to the cheeses, which was attributed to the high water absorption capacity of starch. Fresh Panela cheese is an effective vehicle for delivery of probiotic organisms, the addition of which did not noticeably affect its taste and appearance. This study also demonstrated the feasibility of including probiotic bacteria in a fresh cheese that maintains probiotic viability over its shelf life. Overall, fava bean starch was not an acceptable prebiotic for use in Panela cheese.

\section{ACKNOWLEDGMENTS}

We thank the CINVESTAV-QRO (Querétaro, México), University of Illinois at Urbana-Champaign (Urbana, IL), and PROPAC (Querétaro, México) for the facilities provided for the accomplishment of the present work, CONACYT (México City, México) for the MSc degree scholarship provided for the first author, and ACES Global Connect (Urbana, IL) for the financial support for this project.

\section{REFERENCES}

Aihara, K., O. Kajimoto, H. Hirata, R. Takahashi, and Y. Nakamura. 2005. Effect of powdered fermented milk with Lactobacillus helveticus on subjects with high-normal blood pressure or mild hypertension. J. Am. Coll. Nutr. 24:257-265.

AOAC. 2000. Official Methods of Analysis. Vol. 1. 17th ed. Association of Official Analytical Chemists Int., Gaithersburg, MD.

Bergamini, C. V., E. R. Hynes, M. C. Candioti, and C. A. Zalazar. 2009. Multivariate analysis of proteolysis patterns differentiated 
the impact of six strains of probiotic bacteria on a semi-hard cheese. J. Dairy Sci. 92:2455-2467.

Bergamini, C. V., E. R. Hynes, A. Quiberoni, V. B. Suáez, and C. A. Zalazar. 2005. Probiotic bacteria as adjunct starters: Influence of the addition methodology on their survival in a semi-hard Argentinean cheese. Food Res. Int. 38:597-604.

Blanchette, L., D. Roy, G. Belanger, and S. F. Gauthier. 1996. Production of cottage cheese using dressing fermented by bifidobacteria. J. Dairy Sci. 79:8-15.

Boylston, T. D., C. G. Vinderola, H. B. Ghoddusi, and J. A. Reinheimer. 2004. Incorporation of Bifidobacterium into cheeses: Challenges and rewards. Int. Dairy J. 14:375-387.

Brown, I. L., K. J. McNaught, and E. Moloney. 1995. Hi-maize ${ }^{\mathrm{TM}}$ : New directions in technology and nutrition. Food Aust. 47:272-275.

Castañeda, R. 2002. La reología en la tipificación y la caracterización de quesos. Latin Am. Dairy. Technol. 20:48-53.

Corr, S. C., Y. Li, C. U. Riedel, P. W. O'Toole, C. Hill, and C. G. M. Gahan. 2007. Bacteriocin production as a mechanism for the antiinfective activity of Lactobacillus salivarius UCC118. Proc. Natl. Acad. Sci. USA 104:7617-7621.

Crittenden, R. G., M. L. Morris, M. L. Harvey, L. T. Tran, H. L. Mitchell, and M. J. Playne. 2001. Selection of a Bifidobacterium strain to complement resistant starch in a symbiotic yoghurt. J. Appl. Microbiol. 90:268-278.

De Souza, C. H. B., F. C. A. Buriti, J. H. Behrens, and S. M. I. Saad. 2008. Sensory evaluation of probiotic Minas fresh cheese with Lactobacillus acidophilus added solely or in co-culture with a thermophilic starter culture. Int. J. Food Sci. Technol. 43:871-877.

de Vrese, M., H. Kristen, P. Rautenberg, C. Laue, and J. Schrezenmeir. 2011. Probiotic lactobacilli and bifidobacteria in a fermented milk product with added fruit preparation reduce antibiotic associated diarrhea and Helicobacter pylori activity. J. Dairy Res. 78:396-403.

Dinakar, P., and V. V. Mistry. 1994. Growth and viability of Bifidobacterium bifidum in Cheddar cheese. J. Dairy Sci. 77:2854-2864.

Elmadfa, I., P. Klein, and A. L. Meyer. 2010. Immune-stimulating effects of lactic acid bacteria in vivo and in vitro. Proc. Nutr. Soc. 69:416-420.

Gardiner, G., R. P. Ross, J. K. Collins, G. Fitzgerald, and C. Stanton. 1998. Development of a probiotic cheddar cheese containing human-derived Lactobacillus paracasei strains. Appl. Environ. Microbiol. 64:2192-2199.

Gilliland, S. E., M. L. Speck, and C. G. Morgan. 1975. Detection of $L$. acidophilus in feces of humans, pigs, and chickens. Appl. Microbiol. 30:541-545.

Goñi, I., L. García-Diz, E. Mañas, and F. Saura-Calixto. 1996. Analysis of resistant starch: A method for foods and food products. Food Chem. 56:445-449.

Guillon, F., and M. M. J. Champ. 2002. Carbohydrate fractions of legumes: Uses in human nutrition and potential for health. Br. J. Nutr. 88:S293-S306.

Hayes, M., M. Coakley, M. G. O'Sullivan, C. Stanton, C. Hill, G. F. Fitzgerald, J. J. Murphy, and R. P. Ross. 2006. Cheese as a delivery vehicle for probiotics and biogenic substances. Aust. J. Dairy Technol. 61:132-141

Homayouni, A., A. Azizi, M. R. Ehsani, M. S. Yarmand, and S. H. Razavi. 2008. Effect of microencapsulation and resistant starch on the probiotic survival and sensory properties of synbiotic ice cream. Food Chem. 111:50-55.

Jaros, D., J. Petrag, H. Rohm, and F. Ulberth. 2001. Milk fat composition affects mechanical and rheological properties of processed cheese. Appl. Rheol. 11:19-25.

Jayamanne, V. S., and M. R. Adams. 2006. Determination of survival, identity, and stress resistance of probiotic bifidobacteria in bioyoghurts. Lett. Appl. Microbiol. 42:189-194.

Kleeman, E. G., and T. R. Klaenhammer. 1982. Adherence of Lactobacillus species to human fetal intestinal cells. J. Dairy Sci. 65:2063-2069.

Mäkeläinen, H., S. Forssten, K. Olli, L. Granlund, N. Rautonen, and A. C. Ouwehand. 2009. Probiotic lactobacilli in a semi-soft cheese survive in the simulated human gastrointestinal tract. Int. Dairy J. 19:675-683.

Makino, S., S. Ikegami, A. Kume, H. Horiuchi, H. Sasaki, and N. Orii. 2010. Reducing the risk of infection in the elderly by dietary intake of yoghurt fermented with Lactobacillus delbrueckii ssp. bulgaricus OLL1073R-1. Br. J. Nutr. 104:998-1006.

Mc Brearty, S., R. P. Ross, G. F. Fitzgerald, J. K. Collins, J. M. Wallace, and C. Stanton. 2001. Influence of two commercially available bifidobacteria cultures on Cheddar cheese quality. Int. Dairy J. 11:599-610.

McFarland, L. V. 2007. Meta-analysis of probiotics for the prevention of traveler's diarrhea. Travel Med. Infect. Dis. 5:97-105.

Mills, S., L. M. Serrano, C. Griffin, P. M. O'Connor, G. Schaad, C. Bruining, C. Hill, R. P. Ross, and W. C. Meijer. 2011. Inhibitory activity of Lactobacillus plantarum LMG P-26358 against Listeria innocua when used as an adjunct starter in the manufacture of cheese. Microb. Cell Fact. 10(Suppl. 1):S7.

Montoya, D., T. D. Boylston, and A. Mendonca. 2009. Preliminary screening of Bifidobacteria spp. and Pediococcus acidilactici in a Swiss cheese curd slurry model system: Impact on microbial viability and flavor characteristics. Int. Dairy J. 19:605-611.

Raats, M. M. 1992. The role of beliefs and sensory responses to milk in determining the selection of milks of different fat content. $\mathrm{PhD}$ Diss. University of Reading, UK.

Ratnayake, W. S., R. Hoover, F. Shahidi, C. Perera, and J. Jane. 2001. Composition, molecular structure and physicochemical properties of starches from four field pea (Pisum sativum L.) cultivars. Food Chem. 74:189-202.

Roy, D., I. Mainville, and F. Mondou. 1997. Selective enumeration and survival of bifidobacteria in fresh cheese. Int. Dairy J. 7:785-793.

Sanders, M. E. 2008. Probiotics: Definition, sources, selection, and uses. Clin. Infect. Dis. 46(Suppl. 2):S58-S61; discussion S144-151.

Sharma, A., B. S. Yadav, and B. Y. Ritika. 2008. Resistant starch: Physiological roles and food applications. Food Rev. Int. 24:193234

Shimamura, S., F. Abe, N. Ishibashi, H. Mivakawa, T. Yaeshima, T. Araya, and M. Tomita. 1992. Relationship between oxygen sensitivity and oxygen metabolism of Bifidobacterium species. J. Dairy Sci. 75:3296-3306.

Stanton, C., G. Gardiner, P. B. Lynch, J. K. Collins, G. Fitzgerald, and R. P. Ross. 1998. Probiotic cheese. Int. Dairy J. 18:491-496.

Stanton, C., R. P. Ross, G. F. Fitzgerald, and D. Van Sindersen. 2005 Fermented functional foods based on probiotics and their biogenic metabolites. Curr. Opin. Biotechnol. 16:198-203.

Tharanathan, R. N., and S. Mahadevamma. 2003. Grain legumes-A boon to human nutrition. Trends Food Sci. Technol. 14:507-518.

Tolstoguzov, V. 2003. Some thermodynamic considerations in food formulations. Food Hydrocoll. 17:1-23.

Topping, D. L., and P. Clifton. 2001. Short-chain fatty acids and human colonic function: Roles of resistant starch and nonstarch polysaccharides. Physiol. Rev. 81:1031-1064.

van den Tempel, T., J. K. Gundersen, and M. S. Nielsen. 2002. The microdistribution of oxygen in Danablu cheese measured by a microsensor during ripening. Int. J. Food Microbiol. 75:157-161.

Vinderola, C. G., P. Mocchiutti, and J. A. Reinheimer. 2002. Interactions among lactic acid starter and probiotic bacteria used for fermented dairy products. J. Dairy Sci. 85:721-729.

Vinderola, C. G., W. Prosello, D. Ghiberto, and J. A. Reinheimer. 2000. Viability of probiotic (Bifidobacterium, Lactobacillus acidophilus and Lactobacillus casei) and nonprobiotic microflora in Argentinian fresco cheese. J. Dairy Sci. 83:1905-1911.

Whorwell, P. J., L. Altringer, J. Morel, Y. Bond, D. Charbonneau, L. O'Mahony, B. Kiely, F. Shanahan, and E. M. M. Quigley. 2006. Efficacy of an encapsulated probiotic Bifidobacterium infantis 35624 in women with irritable bowel syndrome. Am. J. Gastroenterol. 101:1581-1590.

Yanagisawa, T., E. Domon, M. Fujita, C. Kiribuchi-Otobe, and T. Takayama. 2006. Starch pasting properties and amylose content from 17 waxy barley lines. Cereal Chem. 83:354-357. 